\title{
QUALITY AND ENERGETIC EVALUATION OF THE CHARCOAL MADE OF BABASSU NUT RESIDUES USED IN THE STEEL INDUSTRY
}

\author{
Qualidade e avaliação energética do carvão vegetal dos resíduos \\ do coco babaçu para uso siderúrgico
}

\author{
Thiago de Paula Protásio', Paulo Fernando Trugilho², \\ Seyedmohammad Mirmehdi' ${ }^{2}$, Marcela Gomes da Silva ${ }^{3}$
}

\begin{abstract}
Brazil is the only country in the world that uses large scale charcoal in steel-making blast furnaces. Meantime, the monoculture plantations of Eucalyptus are not able to meet the demand for charcoal from the steel industries. Therefore, research is necessary, in order to use lignocellulosic residues for the production of charcoal with technological properties which are suitable for the reduction of iron ore. Given the above, the objective of this study was to evaluate the quality of charcoal which was made with babassu nut shell and designed for utilization in the steel industry in the function of the final carbonization temperature. All three layers of babassu nut shell (epicarp, mesocarp and endocarp) were used together. The initial temperature of the test was $100^{\circ} \mathrm{C}$ and the final temperatures were: $450^{\circ} \mathrm{C}, 550^{\circ} \mathrm{C}, 650^{\circ} \mathrm{C}, 750^{\circ} \mathrm{C}$ and $850^{\circ} \mathrm{C}$. For the charcoals produced, the following properties were determined: apparent relative density, energy density and fixed carbon stock, in addition to chemical compositions (immediate and elemental) and heating values (higher and lower). Charcoal made of babassu nut shell showed high values of apparent density and energy density, and has a potential to replace coal and wood charcoal in the steel industry. The effect of the final carbonization temperature was expressed for all characteristics evaluated, except for the nitrogen content. Babassu nut shell must be carbonized at temperatures higher than $550^{\circ} \mathrm{C}$, so that the charcoal produced can be used in steel-making blast furnaces.
\end{abstract}

Index terms: Alternative biomass, renewable energy, bio-reducer, carbonization.

\section{RESUMO}

O Brasil é o único país no mundo que utiliza, em grande escala, o carvão vegetal nos altos fornos siderúrgicos. Contudo, os plantios homogêneos de Eucalyptus não são capazes de suprir a demanda de carvão vegetal das siderúrgicas. Por isso, são necessárias pesquisas visando ao aproveitamento de resíduos lignocelulósicos, para a produção de carvão vegetal com propriedades tecnológicas adequadas à redução do minério de ferro. Dessa forma,objetivou-se, neste trabalho, avaliar a qualidade do carvão vegetal da casca do coco babaçu, destinado ao uso siderúrgico, em função da temperatura final de carbonização. Foram utilizadas, conjuntamente, as três camadas constituintes da casca do coco babaçu (epicarpo, mesocarpo e endocarpo). A temperatura inicial do ensaio foi de $100^{\circ} \mathrm{C}$ e as temperaturas finais foram de $450^{\circ} \mathrm{C}, 550^{\circ} \mathrm{C}, 650^{\circ} \mathrm{C}, 750^{\circ} \mathrm{C}$ e $850^{\circ} \mathrm{C}$. Para os carvões produzidos, foram determinadas as seguintes propriedades: densidade relativa aparente, densidades energéticas e estoque de carbono fixo, além das composições químicas (imediata e elementar) e os poderes caloríficos (superior e inferior). O carvão vegetal da casca do coco babaçu apresentou elevados valores de densidade aparente e de densidade energética e é passível de substituir o carvão mineral e o carvão vegetal de madeira na siderurgia. O efeito da temperatura final de carbonização foi pronunciado para todas as características avaliadas, com exceção do teor de nitrogênio. A casca do coco babaçu deve ser carbonizada em temperaturas superiores a $550^{\circ} \mathrm{C}$, para que o carvão vegetal produzido possa ser utilizado nos altos fornos siderúrgicos.

Termos para indexação: Biomassa alternativa, energia renovável, biorredutor, carbonização.

\section{INTRODUCTION}

Brazil is the only country in the world that uses large scale charcoal as a dual purpose agent in steelmaking blast furnaces, that is, as a source of heat and carbon monoxide (reducing gas of iron ore). Meantime, the monoculture plantations of Eucalyptus are not able to meet the demand for charcoal fromthe steel industries; in other words, there is a shortage of this fuel arising from sustainable sources. The Brazilian steel industry still uses about $35 \%$ to $50 \%$ charcoal from native forests (MMA, 2011; ABRAF, 2012).

Thus, research related to the evaluation of regional biomass, alternatives and residues like the ones from the mechanical processing of wood, coffee wood from crop renewal andbabassu nut residues, which can be used to produce charcoal and meet the specifications of the Brazilian steel industry, is necessary (Protásio et al., 2014a).

\footnotetext{
${ }^{1}$ Universidade Federal de Goiás/UFG - Regional Jataí - Campus Jatobá - Curso de Engenharia Florestal - Cx.P. 3, Rodovia BR-364 - km 192 - Parque Industrial 75801615 - Jataí - GO - Brasil - depaulaprotasio@gmail.com

${ }^{2}$ Universidade Federal de Lavras/UFLA - Departamento de Ciências Florestais/DCF - Lavras - MG - Brasil

3Universidade Federal Rural da Amazônia/UFRA - Belém - PA - Brasil

Received in june 24, 2014 and approved in july 17, 2014
}

Ciênc. Agrotec., Lavras, v.38, n.5, p.435-444, set./out., 2014 
The babassu palm tree is an evergreen and heliophytic,considered the largest native oil-bearing resource in the world. It occurs naturally in Brazil and other Latin American countries such as Mexico, Peru, Colombia and Bolivia (Embrapa, 1984). This palm refers to the three genera of the family Arecaceae: Scheelea, Attalea and Orbignya. Of these, the species Orbignya phalerata Mart. is the most common and widespread (Teixeira, 2008).

Regarding to the bioclimatic zone of babassu palm land in Brazil, three distinct ecological regions can be distinguished: Amazon Rainforest, Cerrado and Caatinga, in which the pioneer species are firmly established, given their high plasticity and adaptability (Embrapa, 1984).

Currently, the researches on babassu focus on the use of the oil of its kernel,which remains, after a manual breaking process, for cosmetic, culinary and fuelusage. Besides kernels, it is possible to produce babassuflour from the mesocarp, since this layer of fruit has about $70 \%$ starch (Nogueira; Lora, 2003).

In recent years, the northeast of Brazil has been responsible for the increased production of babassu nuts, corresponding to almost the total Brazilian production. The state of Maranhão is the largest producer of this region and, consequently, of Brazil, accounting for $94 \%$ of national production (IBGE, 2013). Maranhão has 9.458 million ha of babassu, i.e., approximately $65 \%$ of the national area that is native, with 14.563 million ha (Embrapa, 1984).

According to Dias et al. (2012), domestic production of babassu nut residues (shell) is 1.409 million tons. Teixeira (2008) estimated a Brazilian potential over six million tons of residue, in which the state of Maranhão has the greatest potential (92\%). Therefore, the use of babassu nut shell in Maranhão, for the production of charcoal, could be critical to meet the demand of the three steel plants located there.

Given the considerable supply of babassu nut residue in Brazil and the lack of research related to the analysis of this biomass, the aim of this study was to evaluate the quality of charcoal from babassu nut residue for the steel industry's utilization in its mills' final carbonization temperature.

\section{MATERIAL AND METHODS}

The three layers constituting the shell of the babassu nut, the epicarp, mesocarpand endocarp, were used together for carbonization. The material was collected in the rural municipality of Sítio Novo do Tocantins, Tocantins State $\left(5^{\circ} 36^{\prime} 9^{\prime \prime} \mathrm{S}\right.$ and $\left.47^{\circ} 38^{\prime} 23^{\prime \prime} \mathrm{W}\right)$, and is derived from the manual break of nut held by local communities.
Carbonization was performed in an electric furnace (muffle), with about $500 \mathrm{~g}$ of babassu nut shell used in each test. The samples were previously dried at $103 \pm 2{ }^{\circ} \mathrm{C}$.

The initial test temperature was $100^{\circ} \mathrm{C}$ and the final temperature reached $450^{\circ} \mathrm{C}, 550^{\circ} \mathrm{C}, 650^{\circ} \mathrm{C}, 750^{\circ} \mathrm{C}$ and $850^{\circ} \mathrm{C}$, given a heating rate $1.67^{\circ} \mathrm{C} \mathrm{min}^{-1}\left(100^{\circ} \mathrm{C} \mathrm{h}^{-1}\right)$. The electric furnace remained stableat the final temperature for 30 minutes.

Four replicates were performed for each final temperature. The procedure used in the laboratory carbonization is similar to that found in the literature for Eucalyptus (Pereira et al., 2012; Pereira et al., 2013; Protásio et al., 2013).

The apparent specific gravity of the charcoals was determined according to the hydrostatic method through immersion in water.

The higher heating value of charcoal (HHV) was obtained in duplicate in a digital calorimeter IKA C-200 ${ }^{\circledR}$ according to ASTM E711-87 (ASTM, 2004). The lower heating value (LHV) was calculated based on equation 1 (Kollmann; Cotê, 1968).

$L H V=H H V-\frac{600 \chi 9 H}{100}$

Where: LHV is the lower heating value $\left(\mathrm{kcal} \mathrm{kg}^{-1}\right)$, HHV is the higher heating value $\left(\mathrm{kcal} \mathrm{kg}^{-1}\right)$ and $\mathrm{H}$ is the hydrogen content $(\%)$.

The energy density was obtained by multiplying the HHV and LHV by the apparent relative density of the charcoal, as performed by Pereira et al. (2012) and Protásio et al. (2013). The amount of fixed carbon in charcoal per unit volume (FCS) was calculated by multiplying the apparent density of the fixed carbon content in charcoal. Protásio et al. (2013) took the same approach.

Chemical analysis was performed on the charcoals produced, in order to determine the moisture content, the amount of volatiles (VM), ash (A) and, by difference, fixed carbon (FC), according to the procedure in ASTM D1762-84 (ASTM, 2007).

For chemical analysis, the samples were crushed and sieved. The fraction that passed through the 200 mesh sieve and was retained on the 270 mesh sieve was used. The quantification of the carbon (C), hydrogen $(\mathrm{H})$, nitrogen $(\mathrm{N})$ and sulfur $(\mathrm{S})$, relative to the dry mass of charcoal, was performed in a universal brand Elementar Analyzer (model Vario Micro Cube) in duplicate. 
The oxygen content was determined by difference, i.e., by disregarding the contents of carbon, hydrogen, nitrogen, sulfur and ash. This procedure was also used by Titiladunayo, Mcdonald and Fapetu (2012) and Protásio et al. (2013). We also determined the molar ratios $\mathrm{H} / \mathrm{C}$, $\mathrm{N} / \mathrm{C}$ and $\mathrm{O} / \mathrm{C}$ and the empirical formulas of charcoals produced based on molecular weights of these chemical elements.

Univariate analysis of variance and adjusted linear regression models using completely randomized design (CRD) with four replications and considering them as variation factor ofthe final carbonization temperature, were performed.

Preliminarily, analysis of variance was carried out to the homogeneity of variance (Bartlett's test at $5 \%$ significance) test. In addition, we evaluated the normality of the residuals (Shapiro-Wilk test at 5\% significance). For all the parameters evaluated, no deviations from these analysis assumptions were observed.
All statistical analyzes were performed using the R software version 3.0.1 (R Core Team, 2013) through packages ExpDes (Ferreira; Cavalcanti; Nogueira, 2013) and stats (R Core Team 2013).

\section{RESULTS AND DISCUSSION}

\section{Physical properties of charcoal}

The effect of final carbonization temperature was significant relative to the apparent density, fixed carbon stock and energy densities, as seen in table 1. Low coefficient of variation found in analyzes of variance shows the accuracy of the experiment. Furthermore, it was observed that the coefficients of the fitted models were significant by $t$ test.

It is observed that the apparent relative density of charcoal decreased to $550^{\circ} \mathrm{C}$, and from this carbonization temperature increased significantly (Figure 1), thereby allowing adjustment of a third degree polynomial model (Table 1).

Table 1 - Adjusted models for the estimated relative apparent density (RAD - $\mathrm{kg} \mathrm{m}^{-3}$ ), the fixed carbon stock (FCS - $\mathrm{kg}$ $\left.\mathrm{m}^{-3}\right)$ and energy densities $\left(\mathrm{ED}_{\mathrm{HHV}}\right.$ and $\left.\mathrm{ED}_{\mathrm{LHV}}-\mathrm{GJ} \mathrm{m}^{-3}\right)$.

\begin{tabular}{cccc}
\hline $\mathrm{P}$ & Equation & $\mathrm{R}^{2}$ & $\mathrm{CV}$ \\
\hline $\mathrm{RAD}$ & $\hat{\mathrm{Y}}_{\mathrm{i}}=-2.938 .10^{3}+6.968 .10^{6}\left(1 / \mathrm{X}_{\mathrm{i}}\right)-4.352 .10^{9}\left(1 / \mathrm{X}_{\mathrm{i}}^{2}\right)+8.689 .10^{11}\left(1 / \mathrm{X}_{\mathrm{i}}^{3}\right)$ & $0.74^{* *}$ & 3.83 \\
$\mathrm{FCS}$ & $\hat{\mathrm{Y}}_{\mathrm{i}}=-2.102 .10^{3}+5.232 .10^{6}\left(1 / \mathrm{X}_{\mathrm{i}}\right)-3.269 .10^{9}\left(1 / \mathrm{X}_{\mathrm{i}}^{2}\right)+6.424 .10^{11}\left(1 / \mathrm{X}_{\mathrm{i}}^{3}\right)$ & $0.89^{* *}$ & 3.74 \\
$\mathrm{ED}_{\mathrm{HHV}}$ & $\hat{\mathrm{Y}}_{\mathrm{i}}=-7.727 .10^{1}+1.881 .10^{5}\left(1 / \mathrm{X}_{\mathrm{i}}\right)-1.171 .10^{8}\left(1 / \mathrm{X}_{\mathrm{i}}^{2}\right)+2.321 .10^{10}\left(1 / \mathrm{X}_{\mathrm{i}}^{3}\right)$ & $0.78^{* *}$ & 3.94 \\
$\mathrm{ED}_{\mathrm{LHV}}$ & $\hat{\mathrm{Y}}_{\mathrm{i}}=-7.657 .10^{1}+1.865 .10^{5}\left(1 / \mathrm{X}_{\mathrm{i}}\right)-1.163 .10^{8}\left(1 / \mathrm{X}_{\mathrm{i}}^{2}\right)+2.304 .10^{10}\left(1 / \mathrm{X}_{\mathrm{i}}^{3}\right)$ & $0.81^{* *}$ & 3.97 \\
\hline
\end{tabular}

P: Properties: $\mathrm{X}$ : final carbonization temperature $\left({ }^{\circ} \mathrm{C}\right) ; \mathrm{R}^{2}$ : coefficient of determination; $\mathrm{CV}$ : coefficient of experimental variation (\%); **: Significant at $1 \%$ by F-test.

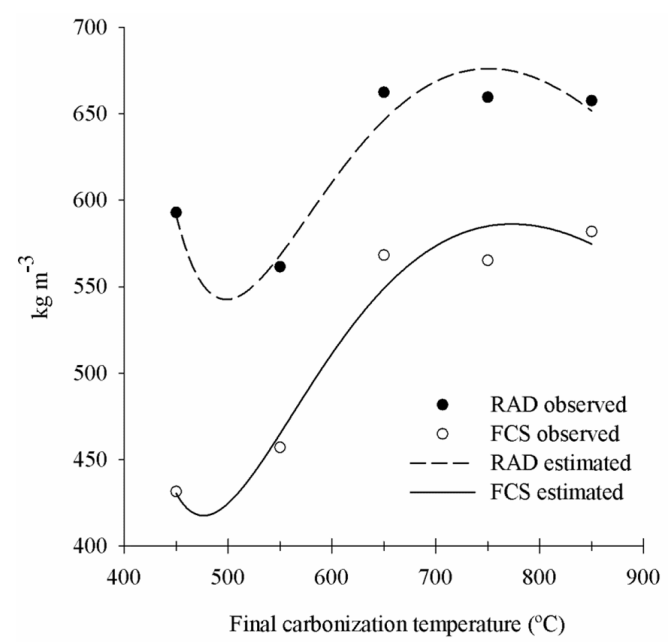

Figure 1 - Effect the final carbonization temperature on the apparent density (RAD) and the fixed carbon stock (FCS) of charcoal from the babassu nut shell. 
This result was also verified by Trugilho and Silva (2001) for the charcoal produced from jatobá (Himenea courbaril L.) wood. The authors carbonized the wood at final temperatures ranging from $300^{\circ} \mathrm{C}$ to $900^{\circ} \mathrm{C}$. However, at $300^{\circ} \mathrm{C}$, the authors stated that the wood was not fully converted into charcoal. The apparent relative density of charcoal from sapwood ranged from $532 \mathrm{~kg}$ $\mathrm{m}^{-3}$ to $557 \mathrm{~kg} \mathrm{~m}^{-3}$ for the final temperatures of $400^{\circ} \mathrm{C}$ and $900^{\circ} \mathrm{C}$, respectively. These values are lower than those observed for charcoal from babassu nut shell produced at temperatures of $450^{\circ} \mathrm{C}$ and $850^{\circ} \mathrm{C}$, that is, $593 \mathrm{~kg} \mathrm{~m}^{-3}$ and $658 \mathrm{~kg} \mathrm{~m}^{-3}$, respectively, and show the potential of the evaluated charcoal for steel use.

The mass loss caused by the release of volatiles between the temperatures of $300^{\circ} \mathrm{C}$ and $500^{\circ} \mathrm{C}$ is much larger than the size reduction of charcoal, which explains the decrease in apparent relative density. As temperature reaches $600^{\circ} \mathrm{C}$ the opposite occurs, i.e., the mass loss is less than the shrinkage of the charcoal (Trugilho; Silva, 2001). This fact is mainly due to volatilization of $\mathrm{H}_{2}$ that has low molecular mass (Yang et al., 2007).

For the fixed carbon stock per unit volume (Figure 1) and energy densities (Figure 2), depending on the final carbonization temperature, the behavior was similar to that found forthe apparent relative density. This demonstrates the positive influence of the density of the charcoal on these characteristics.

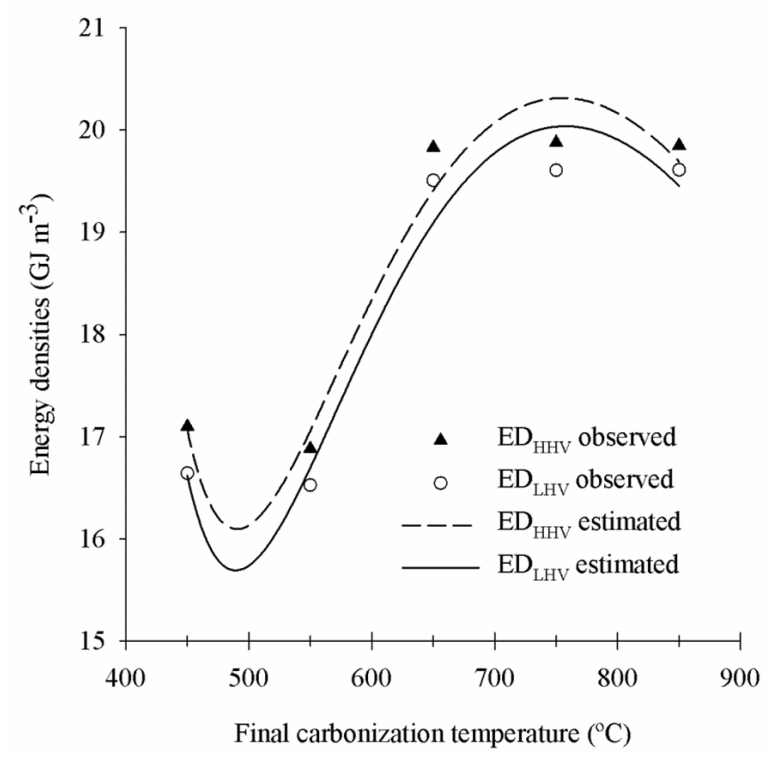

Figure 2 - Effect of the final carbonization temperature on energy densities of charcoal of the babassu nut shell.
For charcoal of young clones of Eucalyptus sp. (42 months) produced with the final temperature of $450^{\circ} \mathrm{C}$ and a rate of $100^{\circ} \mathrm{C} \mathrm{h}^{-1}$, Protásio et al. (2013) observed average apparent density of $340 \mathrm{~kg} \mathrm{~m}^{-3}$, fixed carbon stock average of $267 \mathrm{~kg} \mathrm{~m}^{-3}$ and energy density (HHV base) of $10.49 \mathrm{GJ}$ $\mathrm{m}^{-3}$, or values lower than approximately $74 \%, 61 \%$ and $63 \%$, respectively, to the obtained babassu residue.

Pereira et al. (2012) observed the apparent relative density of charcoal produced with a clone of Eucalyptus urophylla at 90 months, which was produced with the final temperature of $450^{\circ} \mathrm{C}$ and a heating rate of $100^{\circ} \mathrm{C} \mathrm{h}^{-1}, 400$ $\mathrm{kg} \mathrm{m}^{-3}$ and energy density (HHV base) $13 \mathrm{GJ} \mathrm{m}^{-3}$, below those observed in this study at $48 \%$ and $32 \%$, respectively.

Santos et al. (2012), evaluating hybrid genetic material of Eucalyptus at 84 months of age, found that the charcoal produced at the final temperature of $450^{\circ} \mathrm{C}$ had an apparent relative density ranging from 266 to $345 \mathrm{~kg}$ $\mathrm{m}^{-3}$, that is, values considerably lower thanthose observed for charcoal from babassu nut shell.

Similarly, Costa et al. (2014) evaluated the potential use of charcoal from wood of Cerrado species and observed values of apparent relative density ranging from $255 \mathrm{~kg} \mathrm{~m}^{-3}$ to $475 \mathrm{~kg} \mathrm{~m}^{-3}$ for the species Trema micranta and Casearia sylvestris, respectively. The energy density (HHV base) of the charcoal from these species was $8.25 \mathrm{GJ} \mathrm{m}^{-3}$ and $14.62 \mathrm{GJ} \mathrm{m}^{-3}$, respectively. It is worth mentioning that the authors carbonized the wood at the final temperature of $450^{\circ} \mathrm{C}$ at a furnace heating rate of $100^{\circ} \mathrm{C} \mathrm{h}^{-1}$.

These results demonstrate the potential use of charcoal babassu residues in Brazilian steel production, since the great difficulty of using wood charcoal refers to two limiting factors: the low density and low compression resistance (Emmerich, Luengo, 1996). The same authors observed the compressive strength of babassu nut charcoal produced at the final temperature of $600^{\circ} \mathrm{C}$ and $40 \mathrm{MPa}$, and higher than the value found for the coke from mineral coal (15 MPa).

\section{Immediate chemical composition of charcoal}

The effect of final carbonization temperature was statistically significant for the immediate chemical composition of charcoal (Table 2). Analyses of variance showed low coefficients of variation. The adjusted models showed a high coefficient of determination and all were significant at the $5 \% \mathrm{t}$-test level.

Figure 3 shows the sharpest increase in the fixed carbon content of charcoal up to $650^{\circ} \mathrm{C}$ and, thereafter, the increase in fixed carbon content is much smaller with rising temperatures. The volatile materials did not react this way; they decreased their fixed carbon content at the final 
carbonization temperature and had a tendency to stabilize at temperatures above $650^{\circ} \mathrm{C}$. These results are similar to those obtained by Trugilho and Silva (2001), Griessacher, Antrekowitsch and Steinlechner, (2012) and Titiladunayo, Mcdonald and Fapetu (2012).

The produced charcoal at the final temperature of $450^{\circ} \mathrm{C}$ exhibited $73 \%$ fixed carbon, i.e., lower than the maximum of $75 \%$ regulated by the Brazilian steel industry (Rosillo-Calle; Bezzon, 2005). Thus, we recommend the use of charcoal babassu obtained at temperatures above $550^{\circ} \mathrm{C}$ carbonization in the steel industry.

The higher fixed carbon, apart from its utility for use in the steel industry, allows a prolonged burn time of the fuel in applications for energy conversion. This can result in increased efficiency in the use of heat produced by the oxidation of charcoal.

We observed a relative increase in the ash content of charcoal until the temperature of $750^{\circ} \mathrm{C}$ and a further decrease to $850^{\circ} \mathrm{C}$ (Figure 4). This decrease can be explained by the ignition of some mineral components in this temperature range. The same result was observed by Trugilho and Silva (2001).

Compared to coal with an ash content of $8.1 \%$ to 21.4\% (Ward; Zhongsheng; Gurba, 2008; Bragato et al., 2012), babassu charcoal has low mineral content. This is a great advantage in the use of babassu nut shell charcoal as bio-reducer in the steel industry, because the composition of the ash may affect the mechanical properties of pig iron (Pereira et al., 2013), increase corrosion of equipment and decrease the heating value of the fuel.

On the other hand, the charcoal from Eucalyptus wood has an average ash content considerably lower than that found for charcoal from babassu nut shell. In the literature, values lower than $0.90 \%$ are found for charcoal from Eucalyptus wood at ages ranging from 84 to 90 months (Pereira et al., 2012; Reis et al., 2012; Santos et al., 2012). It is worth mentioning that these authors produced charcoal considering the final temperature of $450^{\circ} \mathrm{C}$.

Table 2 - Adjusted models for the estimation of the levels of volatiles (VM), ash (A) and fixed carbon (FC) and a summary of the analysis of variance.

\begin{tabular}{clcc}
\hline $\mathrm{P}$ & \multicolumn{1}{c}{ Equation } & $\mathrm{R}^{2}$ & $\mathrm{CV}$ \\
\hline $\mathrm{VM}_{(\%)}$ & $\hat{\mathrm{Y}}_{\mathrm{i}}=92.467067-0.220291 \mathrm{X}_{\mathrm{i}}+0.0001397 \mathrm{X}_{\mathrm{i}}^{2}$ & $0.99^{* *}$ & 3.39 \\
$\mathrm{~A}_{(\%)}$ & $\hat{\mathrm{Y}}_{\mathrm{i}}=0.00001351+0.00279219 \mathrm{X}_{\mathrm{i}}+0.00003242 \mathrm{X}_{\mathrm{i}}^{2}-0.00000003 \mathrm{X}_{\mathrm{i}}^{3}$ & $0.93^{* *}$ & 7.44 \\
$\mathrm{FC}_{(\%)}$ & $\hat{\mathrm{Y}}_{\mathrm{i}}=13.51024188+0.1846379 \mathrm{X}_{\mathrm{i}}-0.0001146 \mathrm{X}_{\mathrm{i}}^{2}$ & $0.96^{* *}$ & 0.59 \\
\hline
\end{tabular}

$\mathrm{P}$ : Properties; $\mathrm{X}_{\mathrm{:}}$ : final carbonization temperature $\left({ }^{\circ} \mathrm{C}\right) ; \mathrm{R}^{2}$ : coefficient of determination; $\mathrm{CV}$ : coefficient of experimental variation $(\%) ; *$ : Significant at $1 \%$ by F-test.

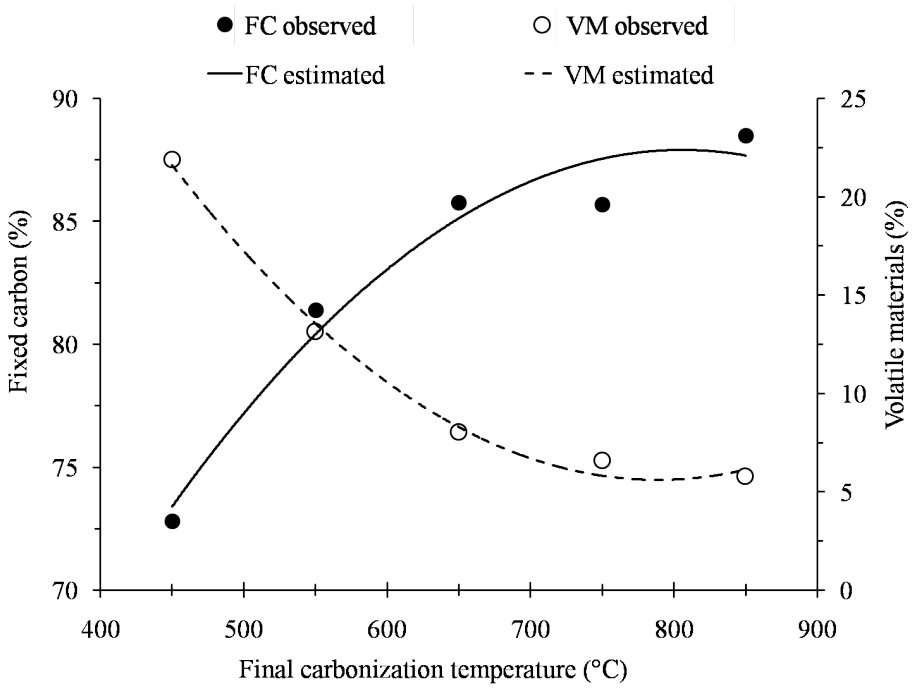

Figure 3 - Levels of fixed carbon (FC) and volatiles (VM) from charcoal babassu nut shell as a function of final carbonization temperature. 


\section{Elemental chemical composition of charcoal}

Table 3 displays the effect of final carbonization temperature, which was significant for carbon, oxygen, hydrogen and sulfur content, as well as the molar ratios $\mathrm{H} / \mathrm{C}$ and $\mathrm{O} / \mathrm{C}$.

This result can also be verified by analyzing the empirical formulas of charcoal produced in the final temperatures of $450^{\circ} \mathrm{C}\left(\mathrm{CH}_{0.54} \mathrm{O}_{0.14} \mathrm{~N}_{0.01}\right), 550^{\circ} \mathrm{C}$ $\left(\mathrm{CH}_{0.41} \mathrm{O}_{0.07} \mathrm{~N}_{0.01}\right), 650^{\circ} \mathrm{C}\left(\mathrm{CH}_{0.31} \mathrm{O}_{0.06} \mathrm{~N}_{0.01}\right), 750^{\circ} \mathrm{C}$ $\left(\mathrm{CH}_{0.25} \mathrm{O}_{0.03} \mathrm{~N}_{0.01}\right)$ and $850^{\circ} \mathrm{C}\left(\mathrm{CH}_{0.22} \mathrm{O}_{0.02} \mathrm{~N}_{0.01}\right)$.

The equations presented were all significant at the $5 \%$ significance level by t-test, with the exception of $\beta_{0}$, which adjusted for sulfur model coefficients, and high coefficients of determination.
High coefficients of variation have been observed regarding sulfur (Table 3). This occurred due to small amounts of sulfur in this charcoal; as a result, small variations lead to a high coefficient of variation.

Given the increase in carbon content and decrease in oxygen content in charcoal with increasing final temperature, carbonization can be seen in figure 5. This result corroborates the findings of Amutio et al. (2012) and Titiladunayo, Mcdonald and Fapetu (2012).

We observed that there is a tendency for the carbon and oxygen to stabilize at temperatures above $800^{\circ} \mathrm{C}$. Titiladunayo, Mcdonald and Fapetu (2012) reported that at higher temperatures, a rearrangement of physical and chemical structures occurs in charcoal; this gives the fuel greater mechanical stability and energy.

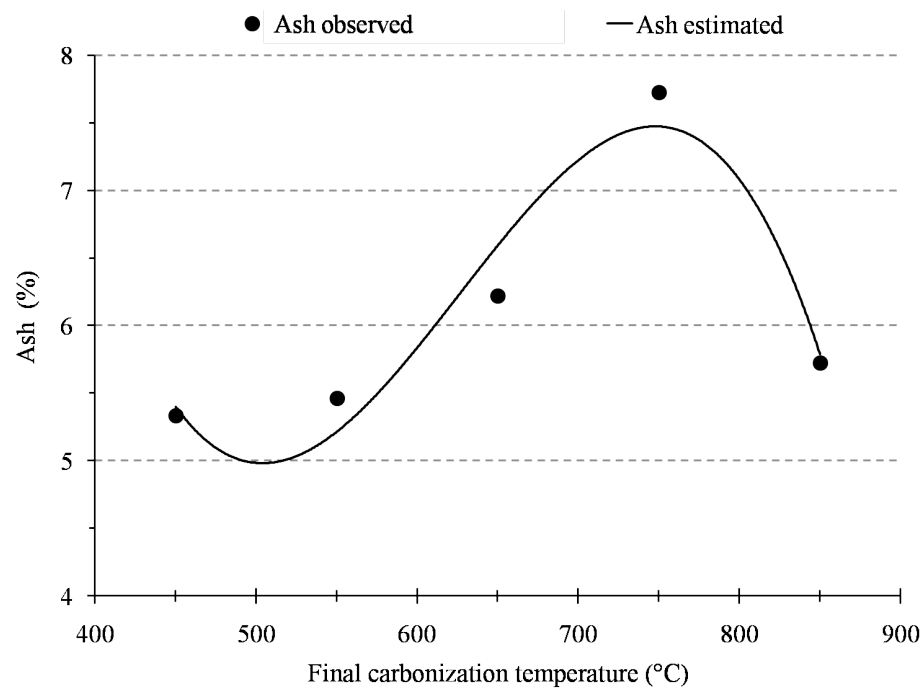

Figure 4 -Ash content of residue babassu nut charcoal in function of the final carbonization temperature.

Table 3 - Adjusted models to estimate the content of the elementary components and molar ratios $\mathrm{H} / \mathrm{C}$ and $\mathrm{O} / \mathrm{C}$, as well as a summary of the analyses of variance performed.

\begin{tabular}{cccc}
\hline Properties & Equation & $\mathrm{R}^{2}$ & $\mathrm{CV}(\%)$ \\
\hline Carbon (\%) & $\hat{\mathrm{Y}}_{\mathrm{i}}=47.006432+0.086150 \mathrm{X}_{\mathrm{i}}-0.000044 \mathrm{X}_{\mathrm{i}}^{2}$ & $0.92^{* *}$ & 1.52 \\
Oxygen (\%) & $\hat{\mathrm{Y}}_{\mathrm{i}}=50.225565-0.109985 \mathrm{X}_{\mathrm{i}}+0.000064 \mathrm{X}_{\mathrm{i}}^{2}$ & $0.94^{* *}$ & 16.43 \\
Hydrogen (\%) & $\hat{\mathrm{Y}}_{\mathrm{i}}=8.580250-0.015005 \mathrm{X}_{\mathrm{i}}+0.000008 \mathrm{X}_{\mathrm{i}}^{2}$ & $0.99^{* *}$ & 5.53 \\
Sulfur (\%) & $\hat{\mathrm{Y}}_{\mathrm{i}}=-0.0211250+0.0001025 \mathrm{X}_{\mathrm{i}}$ & $0.94^{* *}$ & 34.17 \\
Nitrogen (\%) & - & - & 7.94 \\
H/C ratio & $\hat{\mathrm{Y}}_{\mathrm{i}}=1.5421251-0.0029821 \mathrm{X}_{\mathrm{i}}+0.0000017 \mathrm{X}_{\mathrm{i}}^{2}$ & $0.99^{* *}$ & 5.49 \\
O/C ratio & $\hat{\mathrm{Y}}_{\mathrm{i}}=0.5181875-0.0011729 \mathrm{X}_{\mathrm{i}}+0.0000007 \mathrm{X}_{\mathrm{i}}^{2}$ & $0.94^{* *}$ & 19.35 \\
\hline
\end{tabular}

$\mathrm{X}_{\mathrm{i}}$ : final carbonization temperature $\left({ }^{\circ} \mathrm{C}\right) ; \mathrm{R}^{2}$ : coefficient of determination; $\mathrm{CV}$ : coefficient of experimental variation (\%); ${ }^{* *}$ : Significant at $1 \%$ by F-test. 


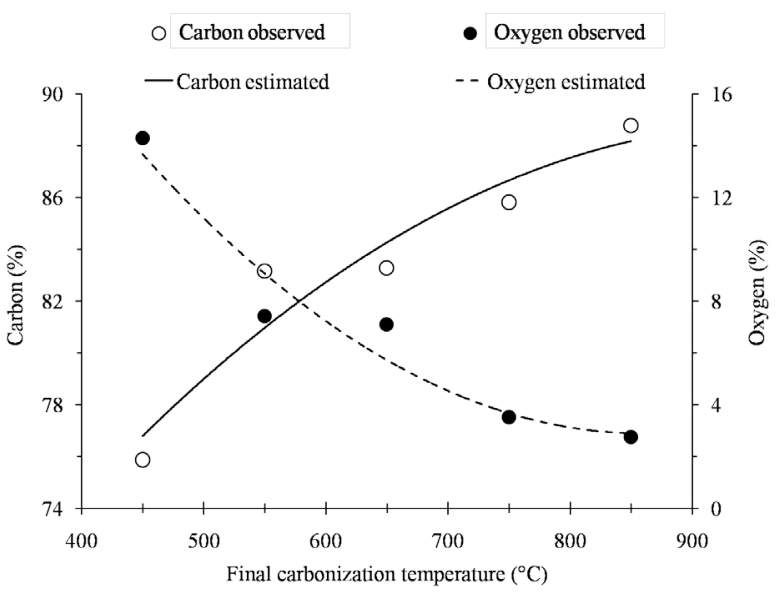

Figure 5 - Levels of carbon and oxygen of charcoal of babassu nut shell in function of the final carbonization temperature.

The main objective is to concentrate carbon from carbonization and reduce the oxygen content and hence improve the energy performance of charcoal. It is known that approximately $90 \%$ of the oxygen present in the biomass is volatilized due to carbonization, while $60 \%$ of the carbon remains retained (Pereira et al. 2013), at a final temperature of $450^{\circ} \mathrm{C}$.

Thus, the increase in temperature and the energy benefits to the steel industry from using charcoal as the carbon source is the main chemical fuel element and is positively associated heating value (Protásio et al., 2011), besides being essential in processing iron ore.

Nitrogen content does not affect the final carbonization temperature (Table 3); we found the average value of $1.13 \%$ $( \pm 0.10)$, differing from that found by Titiladunayo, Mcdonald and Fapetu (2012). This may be due to the type of reactor, heating rate and biomass used by the authors.

Despite the increase in sulfur content at the final carbonization temperature, it may be noted that the increase of that element in charcoal was minimal, i.e., only $0.0001 \%$ for each $1{ }^{\circ} \mathrm{C}$ (Table 3 and figure 6 ). That certainly was due to small amounts of sulfur in not carbonized biomass (Protásio et al., 2014b).

Coal, widely used in steel mills and in thermoelectric plants, has nitrogen and sulfur contents of $2.12 \%$ and $6.29 \%$, respectively (Ward; Zhongsheng; Gurba, 2008). In other words, the values were higher than that found in the charcoal of babassu nut shell, regardless of the carbonization temperature considered.

Protásio et al. (2013) found an average nitrogen content of $1.46 \%$ for charcoal from Eucalyptus clones, that is, a value higher than that found for babassu nut charcoal.
These authors did not detect sulfur in the elemental composition of this biofuel.

It is known that during the complete combustion of charcoal, these elements are converted into toxic oxides $\left(\mathrm{NO}_{\mathrm{x}}\right.$ and $\left.\mathrm{SO}_{\mathrm{x}}\right)$ and thus contribute to air pollution. In addition, sulfur is a pollutant of pig iron and impairs its mechanical properties.

A marked reduction of the hydrogen content in charcoal (Figure 6) was observed with the addition of the final carbonization temperature, found to be $3.4 \%$ at a temperature of $450^{\circ} \mathrm{C}$ and $1.6 \%$ at $850^{\circ} \mathrm{C}$, resembling the trends found by Titiladunayo, Mcdonald and Fapetu (2012).

In figure 7 we can observe a sharp decline in molar ratios $\mathrm{H} / \mathrm{C}$ and $\mathrm{O} / \mathrm{C}$ at lower temperatures and the tendency to stabilize at high temperatures.

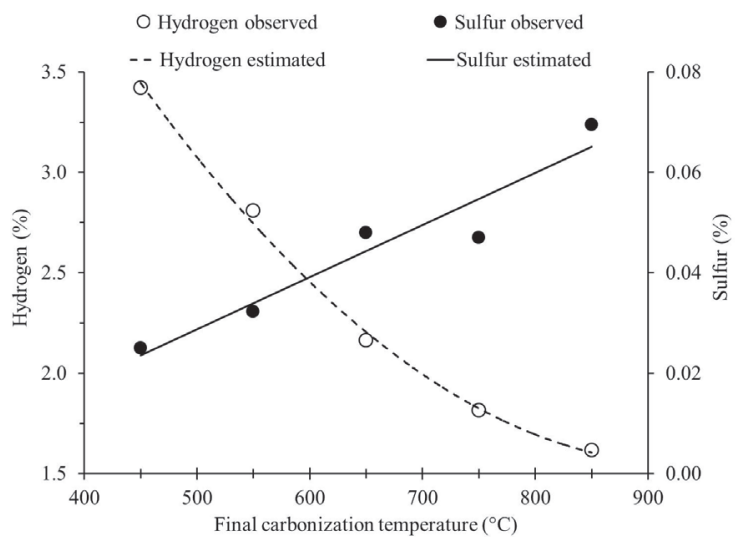

Figure 6 - Hydrogen and sulfur contents in charcoal of babassu nut shell in the function of the final carbonization temperature.

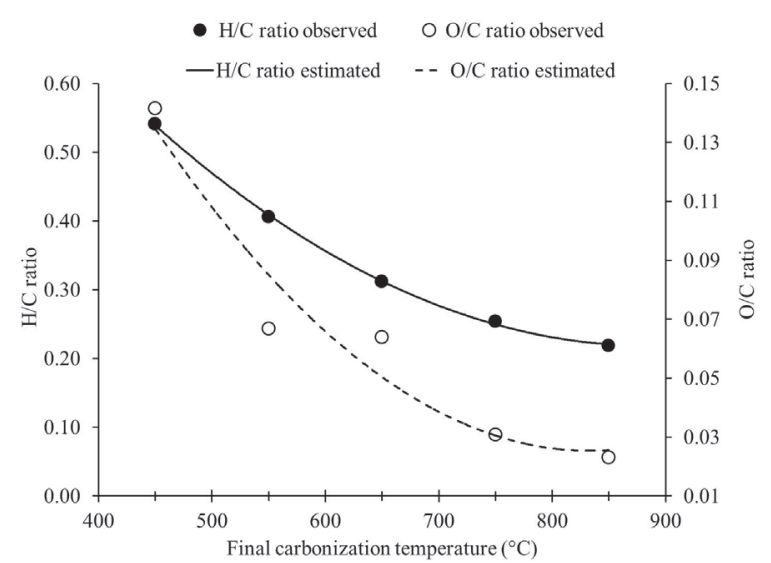

Figure 7 - Effect of final carbonization temperature H/C and $\mathrm{O} / \mathrm{C}$ in molar ratios of charcoal of babassu nut shell. 
This result can be explained due to the increase of carbon content and decreasing levels of hydrogen and oxygen in charcoal with the final carbonization temperature, as shown in figures 5 and 6 .

From an energy point of view it is desirable to minimize the oxygen content in charcoal and maximize the amount of carbon; consequently, the $\mathrm{H} / \mathrm{C}$ and $\mathrm{O} / \mathrm{C}$ ratios will be reduced.

\section{Heating value of charcoal}

The effect of the final carbonization temperature was statistically significant for any measured heating values (Table 4 and figure 8).

Analyzing figure 8 , it can be seen that there is a tendency to stabilize the higher and lower heating values at higher temperatures. These results from the trends observed for the contents of elemental carbon, fixed carbon and oxygen, and for the $\mathrm{H} / \mathrm{C}$ and $\mathrm{O} / \mathrm{C}$ molar ratios of charcoal in the function of the final carbonization temperature.

Protásio et al. (2013) found higher and lower heating values for charcoal clones of Eucalyptus sp., at 42 months of age and carbonized in the laboratory at the final temperature of $450^{\circ} \mathrm{C}: 30.91$ and 30.20 $\mathrm{MJ} \mathrm{kg}{ }^{-1}$, respectively. Based on the same laboratory procedure, Pereira et al. (2012) observed a higher heating value, ranging from $29.60 \mathrm{MJ} \mathrm{kg}^{-1}$ to 31.89 MJ kg-1 for wood charcoal from six Eucalyptus spp. clones at 90 months of age.

These values are close to those found for babassu nut charcoal, produced at that same final carbonization temperature, and demonstrate that this raw material presents energy efficiency similar to that of charcoal from Eucalyptus.

Trugilho and Silva (2001) evaluated the effect of the final carbonization temperature on the quality of charcoal produced from jatobá (Himenea courbaril L.) wood, and found a similar increasing trend of the higher heating value. The authors observed values of $22.42 \mathrm{MJ}$ $\mathrm{kg}^{-1}, 25.16 \mathrm{MJ} \mathrm{kg}^{-1}, 30.81 \mathrm{MJ} \mathrm{kg}^{-1}, 31.22 \mathrm{MJ} \mathrm{kg}^{-1}, 31.95$ $\mathrm{MJ} \mathrm{kg}^{-1}$ and $33.04 \mathrm{MJ} \mathrm{kg}^{-1}$ for the charcoal produced at the final temperatures of $400^{\circ} \mathrm{C}, 500^{\circ} \mathrm{C}, 600^{\circ} \mathrm{C}, 700^{\circ} \mathrm{C}$, $800^{\circ} \mathrm{C}$ and $900^{\circ} \mathrm{C}$, respectively.

Table 4 - Adjusted models for the estimated higher heating value (HHV) and lower heating value (LHV), as well as a summary of the analyses of variance performed.

\begin{tabular}{cccc}
\hline Properties & Equation & $\mathrm{R}^{2}$ & $\mathrm{CV}(\%)$ \\
\hline HHV $\left(\mathrm{MJ} \mathrm{kg}^{-1}\right)$ & $\hat{\mathrm{Y}}_{\mathrm{i}}=22.289811+0.021316 \mathrm{X}_{\mathrm{i}}-0.000014 \mathrm{X}_{\mathrm{i}}^{2}$ & $0.83^{*}$ & 1.23 \\
LHV $\left(\mathrm{MJ} \mathrm{kg}^{-1}\right)$ & $\hat{\mathrm{Y}}_{\mathrm{i}}=20.357373+0.024671 \mathrm{X}_{\mathrm{i}}-0.000016 \mathrm{X}_{\mathrm{i}}^{2}$ & $0.90^{* *}$ & 1.23 \\
\hline
\end{tabular}

$\mathrm{X}_{\mathrm{i}}$ : final carbonization temperature $\left({ }^{\circ} \mathrm{C}\right) ; \mathrm{R}^{2}$ : coefficient of determination; $\mathrm{CV}$ : coefficient of experimental variation; *: Significant at $5 \%$ by F-test; $* *$ : Significant at $1 \%$ by F-test.

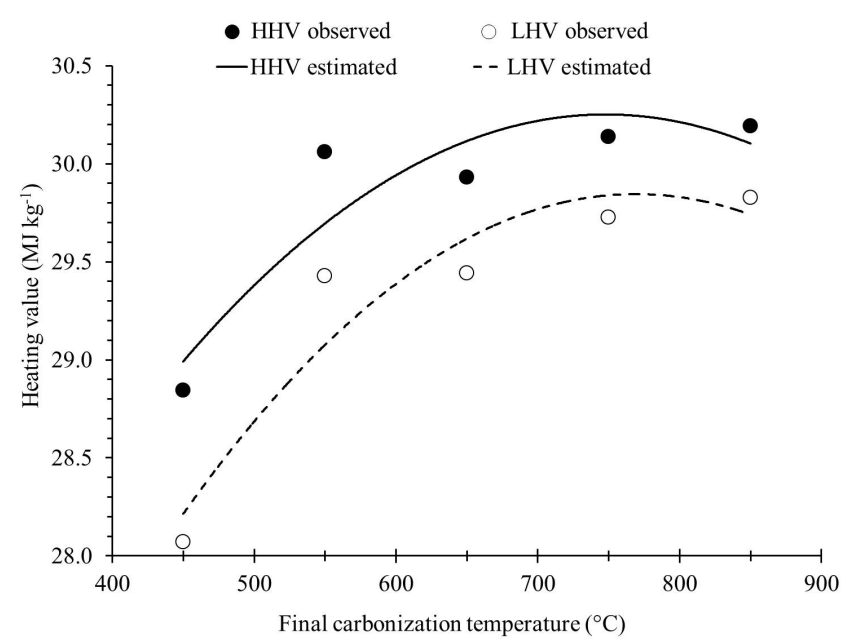

Figure 8 - Effect of the final carbonization temperature on higher heating value (HHV) and the lower heating value (LHV) of charcoal of babassu nut shell. 


\section{CONCLUSIONS}

The charcoal babassu nut shell showed high values of apparent density and energy density, possesses chemical and energetic properties suitable for industrial use, and can be considered as a potential replacement of coal and wood charcoal in the steel industry.

Based on the results found, it is recommended that the babassu nut shell be carbonized at temperatures higher than $550^{\circ} \mathrm{C}$, so that the charcoal produced can be used in steel-making blast furnaces.

The effect of the final carbonization temperature was discussed for all of the characteristics of the charcoal evaluated, with the exception of nitrogen content.

It is possible to observe a decrease in apparent relative density, fixed carbon stock and energy densities until $550^{\circ} \mathrm{C}$, and then and increase until $850^{\circ} \mathrm{C}$.

The ash content in charcoal increased until $750^{\circ} \mathrm{C}$, and then decreased at $850^{\circ} \mathrm{C}$. On the other hand, the contents of fixed carbon, elemental carbon and sulfur, as well as the heating values, increased with the final carbonization temperature. The opposite was found for the contents of volatile materials, oxygen and hydrogen, and for the ratios $\mathrm{H} / \mathrm{C}$ and $\mathrm{O} / \mathrm{C}$.

\section{ACKNOWLEDGEMENTS}

The authors would like to thank CNPq for the financial support and fellowship (processes 132431/2013-0 and 141439/2014-9).

\section{REFERENCES}

AMERICAN SOCIETY FOR TESTING MATERIALS ASTM. ASTM E711-87: Standard Test Method for Gross Calorific Value of Refuse-Derived Fuel by the Bomb Calorimeter. Philadelphia: ASTM International, 2004. 8p.

\section{AMERICAN SOCIETY FOR TESTING MATERIALS}

- ASTM. ASTM D 1762-84: Standard method for chemical analyses of wood charcoal. Philadelphia: ASTM International, 2007. 2p.

AMUTIO, M. et al Influence of temperature on biomass pyrolysis in a conical spouted bed reactor. Resources,

Conservation and Recycling, v. 59:23-31, 2012.

\section{ASSOCIAÇÃO BRASILEIRA DE PRODUTORES}

DE FLORESTAS PLANTADAS - ABRAF. Anuário

estatístico da ABRAF 2012: ano base 2011. Brasília, DF: ABRAF, 2012. 150p.
BRAGATO, M. et al. Combustion of coal, bagasse and blends thereof: Part II: Speciation of PAH emissions.

Fuel. 96:51-58, 2012.

COSTA, T. G. et al. Qualidade da madeira de cinco espécies de ocorrência no cerrado para produção de carvão vegetal. Cerne. 20(1):37-46, 2014.

DIAS, J. M. C. S. et al. Produção de briquetes e péletes a partir de resíduos agrícolas, agroindustriais e florestais. Brasília, DF: EmbrapaAgroenergia, 2012. 130 p.

EMMERICH, F. G.; LUENGO, C. A. Babassu charcoal: a sulfurless renewable thermo-reducing feedstock for steelmaking. Biomass and Bioenergy. 10:41-44, 1996.

\section{EMPRESA BRASILEIRA DE PESQUISA}

AGROPECUÁRIA - EMBRAPA. Babaçu: Programa Nacional de Pesquisa. Departamento de Orientação e Apoio à Programação de Pesquisa: Brasília, 1984. 89p.

FERREIRA, E. B.; CAVALCANTI, P. P.; NOGUEIRA, D. A. ExpDes: Experimental designs package. $R$ package version 1.1.2. 2013. Available at: $<\mathrm{http}: / /$ cran.r-project.org/web/packages/ExpDes/index.html>. Access:26 Nov. 2013.

GRIESSACHER,T;; ANTREKOWITSCH, J.; STEINLECHNER, S. Charcoal from agricultural residues as alternative reducing agent in metal recycling. Biomass and Bioenergy. 39:139-146, 2012.

INSTITUTO BRASILEIRO DE GEOGRAFIA E ESTATÍSTICA - IBGE. Sistema IBGE de recuperação automática - SIDRA. Extração vegetal. 2013.

Availableat: $<$ http://www.sidra.ibge.gov.br/bda/tabela/ listabl.asp? $\mathrm{z}=\mathrm{t} \& \mathrm{o}=18 \& \mathrm{i}=\mathrm{P} \& \mathrm{c}=289>$. Access $: 26 \mathrm{Nov}$. 2013.

KOLLMANN, F.F.P.; COTÊ, W.A. Principles of wood science and technology. Berlin: Springer Verlag, 1968. 592 p.

MINISTÉRIO DO MEIO AMBIENTE. Plano de ação para prevenção e controle do desmatamento e das queimadas: cerrado. Brasília: MMA, 2011. 200p.

NOGUEIRA, L. A. H.; LORA, E. E. S. Dendroenergia: fundamentos e aplicações. 2. ed. Rio de Janeiro: Interciência, 2003. 199p. 
PEREIRA, B. L. C. et al. Quality of wood and charcoal from Eucalyptus clones for ironmaster use.

International Journal of Forestry Research. 20:1-8, 2012.

PEREIRA, B. L. C. et al. Influence of chemical composition of Eucalyptus wood on gravimetric yield and charcoal properties. Bioresources. 8:4574-4592, 2013.

PROTÁSIO, T. P. et al. Relação entre o poder calorífico superior e os componentes elementares e minerais da biomassa vegetal. Pesquisa Florestal Brasileira. 31(66):122-133, 2011.

PROTÁSIO, T. P. et al. Potencial siderúrgico e energético do carvão vegetal de clones de Eucalyptus spp. aos 42 meses de idade. Pesquisa Florestal Brasileira. 33:137-149, 2013.

PROTÁSIO, T. P. et al. Babassu nut residues: potential for bioenergy use in the North and Northeast of Brazil. SpringerPlus. 3(124):1-14, $2014 \mathrm{~b}$.

PROTÁSIO, T. P. et al. Mass and energy balance of the carbonization of babassunutshell as affected by temperature. Pesquisa Agropecuária Brasileira. 49(3):189-196, 2014a.

R CORE TEAM. R: A language and environment for statistical computing. R Foundation for Statistical Computing, Vienna, Austria. 2013. Disponível em: http://www.R-project.org/. Acesso em 07 abril. 2013.

REIS, A. A. et al. Composição da madeira e do carvão vegetal de Eucalyptus urophylla em diferentes locais de plantio. Pesquisa Florestal Brasileira. 32(71):277-290, 2012.

ROSILLO-CALLE, F.; BEZZON, G. Produção e uso industriais do carvão vegetal. In: ROSILLO-CALLE, F.; BAJAY, S. V.; ROTHMAN, H. Uso da biomassa para a produção de energia na indústria brasileira. Campinas, SP: Unicamp, 2005. 447p.

SANTOS, R. C. et al. Análise termogravimética em clones de eucalipto como subsídio para a produçào de carvão vegetal. Cerne. 18(1):143-151, 2012.

TEIXEIRA, M. A. Babassu - a new approach for an ancient Brazilian biomass. Biomass and Bioenergy. 32;857-864, 2008.

TITILADUNAYO, I. F.; MCDONALD, A. G.; FAPETU, O. P. Effect of temperature on biochar product yield from selected lignocellulosic biomass in a pyrolysis process. Waste and Biomass Valorization. 3:311-318, 2012.

TRUGILHO, P. F.; SILVA, D. A. Influência da temperatura final de carbonização nas características físicas e químicas do carvão vegetal de jatobá (Himenea courbaril L.). Scientia Agraria. 2:45-53, 2001.

WARD, C. R.; ZHONGSHENG, L.; GURBA, L. W. Comparison of elemental composition of macerals determined by electron microprobe to whole-coal ultimate analysis data. International Journal of Coal Geology. 75:157-165, 2008.

YANG, H. et al. Characteristics of hemicellulose, cellulose and lignin pyrolysis. Fuel. 86:1781-1788, 2007. 